\title{
Sugarcane Bud Chip Encapsulation for ex vitro Synthetic Seed Formation
}

\author{
Janniffer C. da Silva ${ }^{1}$, Aurélio R. Neto ${ }^{2}$, Eduardo da Costa Severiano ${ }^{1}$, Fabiano G. Silva ${ }^{1} \&$ Diego P. Dornelles ${ }^{1}$ \\ ${ }^{1}$ Goiano Federal Institute of Education, Science and Technology, Rio Verde Campus, Rio Verde, GO, Brazil \\ ${ }^{2}$ Arco Norte Rede, Center for Innovation, Goiano Federal Institute, Rio Verde Campus, Rio Verde, GO, Brazil \\ Correspondence: Janniffer C. da Silva, Instituto Federal de Educação, Ciência e Tecnologia Goiano, Campus Rio \\ Verde, Rodovia Sul Goiana, Km 01, s/n-Zona Rural, Caixa Postal 66, CEP 75901-970, Rio Verde, GO, Brazil. \\ E-mail: silva.janniffer@gmail.com
}

Received: December 26, 2017

Accepted: January 30, 2018

Online Published: March 15, 2018

doi:10.5539/jas.v10n4p104

URL: https://doi.org/10.5539/jas.v10n4p104

\begin{abstract}
Altough the sugarcane crop had a huge world importance the planting system stil the same since the development, needing changes to increase the procution potential. So, the objective of this study was to assess the effect of sugarcane bud chip encapsulation on the initial growth of seedlings. To provide informations for a new planting system, using small stem pieces of sugarcane to produce the seedlings. Two experiments were conducted in a completely randomized design. In the first, bud chip encapsulation was assessed with six concentrations of sodium alginate $\left(0,10,20,30,40\right.$, and $\left.50 \mathrm{~g} \mathrm{~L}^{-1}\right)$ cross-linked with $300 \mathrm{mM}$ calcium chloride, with the encapsulated chips being kept in a greenhouse. In the second experiment, the capsules resulting from the different sodium alginate concentrations were tested for the dry mass adhered to the bud chip, moisture, swelling index, biodegradability, and solubility. Emergence greater than $70 \%$ was obtained at sodium alginate concentrations of 0,10 , and $20 \mathrm{~g} \mathrm{~L}^{-1}$. The 30,40 , and $50 \mathrm{~g} \mathrm{~L}^{-1}$ concentrations inhibited seedling emergence and initial growth; however, when the capsule was removed, the bud chips formed viable seedlings. Encapsulation inhibited emergence because the capsule acts as a physical barrier; however, encapsulation may be used for bud chip preservation. The study of new capsules and encapsulation methods may enable the ex vitro production of synthetic sugarcane seeds.
\end{abstract}

Keywords: propagation, Saccharum sp., sodium alginate

\section{Introduction}

Sugarcane (Saccharum sp.) is a perennial crop, traditionally propagated by axillary bud proliferation, requiring 18 to $20 \mathrm{t} \mathrm{ha}^{-1}$ of stalks for its cultivation. In the conventional tillage system, the use of stalks has plant protection limitations and has led to the development of the Pre-Sprouted Seedlings (PSS) system by the Agronomic Institute of Campinas (Instituto Agronômico de Campinas-IAC; Landell et al., 2013). PSS uses only the 3 -cm-long axillary bud region containing the reserves, termed the bud chip, to obtain seedlings that will be grown in the field. This ensures the health and homogeneity of the sugarcane field and reduces the consumption of raw material for planting to approximately $2 \mathrm{t} \mathrm{ha}^{-1}$ (Gomes, 2013). Because this method is currently in demand, several studies are being conducted to enable faster production of the seedlings with greater vigor (Gírio et al., 2015).

The synthetic seed method is conventionally applied to propagules smaller than $1 \mathrm{~cm}$ in vitro, which are taken to the field after acclimatization. Studies on the formation of synthetic sugarcane seeds are being conducted to optimize the planting system of this crop (Passarin, Fernandes, \& Perticarrari, 2014).

Encapsulation is a method used to form synthetic seeds of plant propagules under in vitro conditions to increase propagule viability and resistance to adverse environmental conditions (Hung \& Trueman, 2011). Currently, sodium alginate cross-linked with calcium chloride is the most commonly used reagent for synthetic seed formation, and the optimal concentration of these products varies with the study species. Although this is a promising technology in plant propagation, its use is limited to in vitro environments, short-term storage, and cryopreservation (Sharma, Shahzad, \& da Silva, 2013). 
Thus, studying sugarcane bud chip encapsulation may clarify the processes of ex vitro synthetic sugarcane seed formation, shorten seedling production time, and increase seedling viability and survival in the field. Therefore, the aim of this study was to assess sugarcane bud chip encapsulation with different concentrations of sodium alginate in the initial growth of sugarcane seedlings.

\section{Materials and Methods}

\subsection{Study Site and Plant Material Origin}

The study was conducted in the greenhouse of the Laboratory of Plant Tissue Culture, Federal Institute of Goiás (Instituto Federal Goiano-IF Goiano), Rio Verde Campus (1748'17.137"S 5054'21.693"W and 748 m above sea level). The sugarcane propagation system was adapted from Landell et al. (2013). The cultivar CTC 4 was used because it is one of the most planted in Brazil, is adapted to the conditions of Goiás, remains productive throughout the cuts, tolerates drought, and shows high tillering (Braga et al., 2017). This cultivar was provided by the São Martinho Mill, located in Quirinópolis, Goiás.

\subsection{Saccharum sp. L. Bud Chip Encapsulation}

Bud chips were collected from the field, and their size was standardized to $3 \mathrm{~cm}$ using a guillotine. Then, they were rinsed in running water, immersed in a $0.25 \%$ solution of the fungicide Frowncide ${ }^{\circledR}$ for 1 minute, and dried on paper towels for 3 minutes to remove the excess moisture. After the chemical treatment, the bud chips were dipped in sodium alginate solution at concentrations of 10,20,30,40, and $50 \mathrm{~g} \mathrm{~L}^{-1}$, prepared by dilution in water and shaken at 18,000 rpm for 3 minutes, based on Kaya \& Souza (2017) using sodium alginate on shoot tips encapsulation. Then, the bud chips were transferred with tweezers to a $300-\mathrm{mM}$ calcium chloride solution (defined in previous tests), where they remained for 5 minutes under shaking at $90 \mathrm{rpm}$. Subsequently, they were rinsed three times in water and left on paper towels for 1 hour to remove the excess moisture (Hung \& Trueman, 2011). Bud chips not immersed in the encapsulation solution were used as controls (Figure 1).
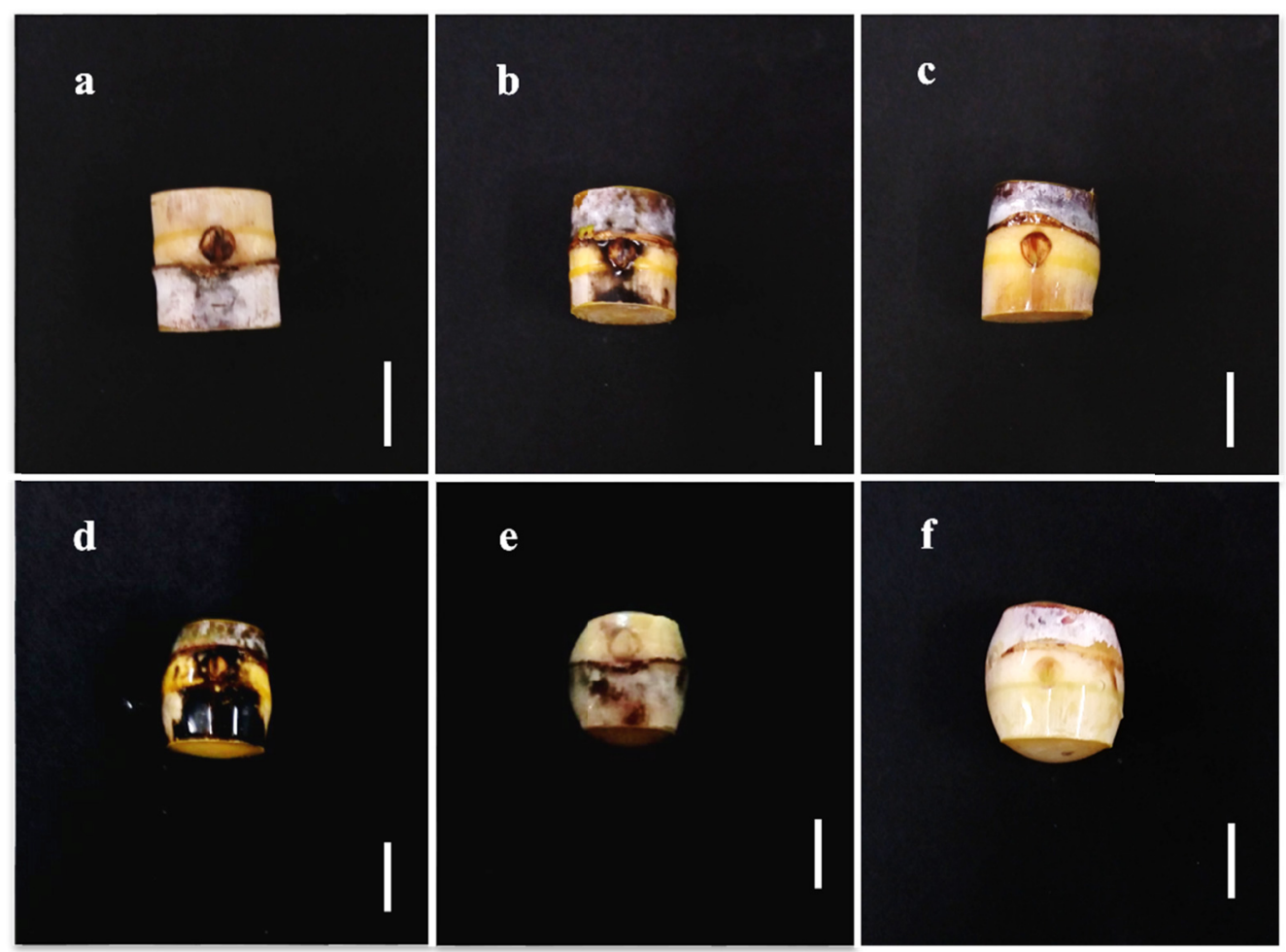

Figure 1. Photographs of Saccharum sp. L. bud chips encapsulated with different concentrations of sodium alginate cross-linked with $300 \mathrm{mM}$ calcium chloride. Zero (a), $10 \mathrm{~g} \mathrm{~L}^{-1}$ (b). $20 \mathrm{~g} \mathrm{~L}^{-1}$ (c), $30 \mathrm{~g} \mathrm{~L}^{-1}$ (d), $40 \mathrm{~g} \mathrm{~L}^{-1}$ (e), and $50 \mathrm{~g} \mathrm{~L}^{-1}$ (f). Source: Janniffer Custódio da Silva. September 2016. Bars: $2 \mathrm{~cm}$ 
After the encapsulation, the bud chips were planted in Styrofoam trays with Bioplant ${ }^{\circledR}$ commercial substrate. The trays were kept in a greenhouse, provided with 10-mm daily irrigation, and divided into four groups until emergence stabilized. Emergence was assessed 3 days after the last bud chip emerged, which was 31 days after planting (DAP).

The percent emergence, as well as the emergence speed index (ESI) - evaluated daily and calculated using the formula by Maguire (1962)—were assessed during the experiment. Biometric analyses were performed at the time of transplantation to monitor the initial growth, analyzing the following variables: number of leaves, stem diameter, longest root length, shoot length, and plant length.

At the end of the cultivation, the plants were collected and separated from the bud chips to determine the shoot dry mass (SDM), root dry mass (RDM), and total dry mass (DMtotal), which was obtained by summing the SDM and RDM. The plants were then dried at $65^{\circ} \mathrm{C}$ in a forced air oven to constant weight.

To explain the biological behavior of the percent emergence as a function of DAP, the three-parameter, nonlinear regression models with the following equation described by Borges et al. (2016) were used:

$$
\mathrm{Y}=\mathrm{a} /\left\{1+\exp \left[-\left(\mathrm{x}-\mathrm{x}_{0}\right) / \mathrm{b}\right]\right\}
$$

where, $\mathrm{a}=$ the curve maximum $(100 \%$ emergence $) ; \mathrm{b}=$ the adjustment parameter; $\mathrm{x}_{0}=$ the " $\mathrm{x}$ " point at which emergence reached $50 \%$.

After emergence stabilized, 31 DAP, the bud chips that produced viable seedlings, which included those encapsulated at 0,10 , and $20 \mathrm{~g} \mathrm{~L}^{-1}$ sodium alginate with emergence higher than $70 \%$, were transplanted to $290-\mathrm{cm}^{3}$ test tubes and pruned to avoid water loss through evapotranspiration and to stimulate root growth (Landell et al., 2013). The bud chips that failed to show emergence when encapsulated at 30,40 , and $50 \mathrm{~g} \mathrm{~L}^{-1}$ sodium alginate were subjected to the viability test, which consisted of the manual removal of the capsule and replanting in Styrofoam trays. The cultivation and evaluations were conducted as described above.

During the study period (15 September 2016 to 18 December 2016), the mean maximum temperature was $38.7{ }^{\circ} \mathrm{C}$, and the mean minimum temperature was $18.7{ }^{\circ} \mathrm{C}$, with $63.8 \%$ humidity; these parameters were monitored using a thermos-hygrometer (Porto Alegre, RS, INCOTERM-7663).

\subsection{Evaluations of the Capsules used to Encapsulate the Saccharum sp. L. Bud Chips}

Concurrently with the encapsulation test, the films produced using the different sodium alginate concentrations were assessed for their ability to adhere to the bud chip, with measurements being made of the bud chip-adhered film dry mass (BCAFDM). For this purpose, the bud chips were kept at room temperature for 16 hours for initial drying, the adhered film was subsequently removed using tweezers and scalpel, and the film was dried in a forced air oven at $65^{\circ} \mathrm{C}$ to constant weight.

The moisture content, swelling index, biodegradability on substrate, and water solubility were analyzed to characterize the films used in the encapsulation. For this purpose, the films were prepared with $10 \mathrm{~mL}$ of the sodium alginate solutions deposited in polystyrene Petri dishes by syringe, cross-linked with $10 \mathrm{~mL}$ of $300 \mathrm{mM}$ calcium chloride solution while being shaken at $90 \mathrm{rpm}$ for 5 minutes, and rinsed in water three times. After film formation, the films were incubated at $35^{\circ} \mathrm{C}$ for 16 hours and kept in a desiccator for 72 hours (Figure 2).
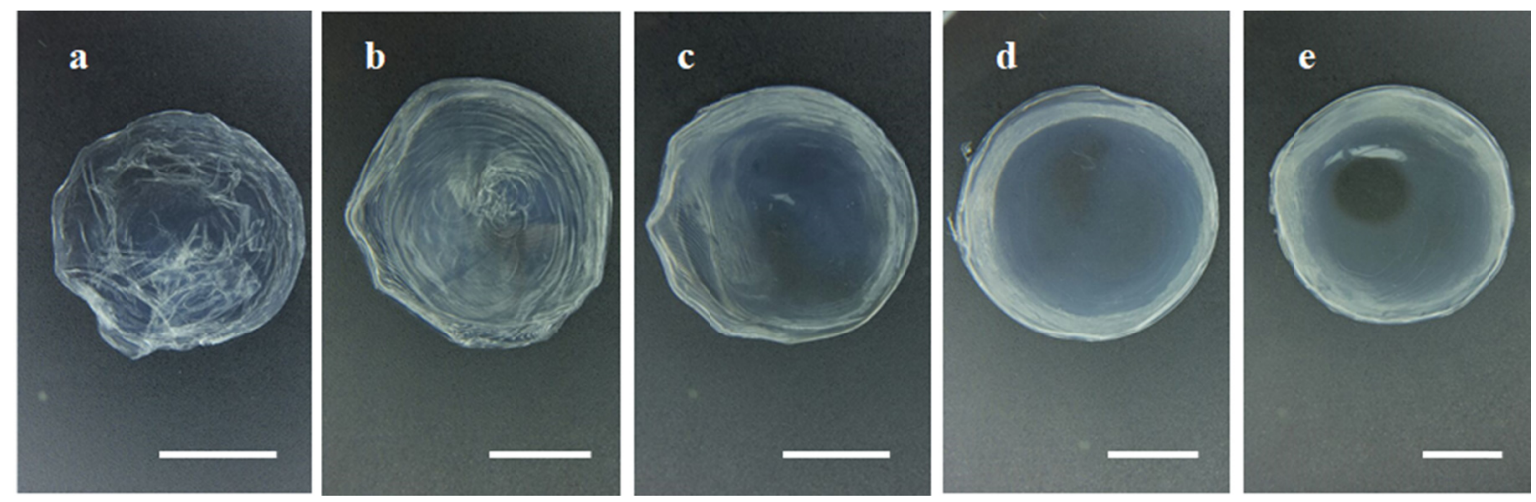

Figure 2. Photographs of sodium alginate films cross-linked with $300 \mathrm{mM}$ calcium chloride. 10 (a), 20 (b); 30 (c), 40 (d), and $50 \mathrm{~g} \mathrm{~L}^{-1}$ (e). Source: Janniffer C. Silva. September 2016. Bars: $3 \mathrm{~cm}$ 
The biofilm moisture content was determined in $4-\mathrm{cm}^{2}$ circular film incubated in an oven at $105{ }^{\circ} \mathrm{C}$ for 24 hours and assessed by gravimetry.

The swelling index was determined based on the method proposed by Almeida, Prestes, Pinheiro, Woiciechowski, and Wosiacki (2013) with modifications. Accordingly, 2.7- $\mathrm{cm}^{2}$ circular film samples were removed and dried at $65^{\circ} \mathrm{C}$ to constant weight. Then, the samples were immersed in an Erlenmeyer containing $50 \mathrm{~mL}$ distilled water for 40 minutes. After this period, the samples were removed with tweezers and placed between filter paper sheets for 1 minute. The hydrated films were reweighed. The swelling index (Si) was calculated using the following equation:

$$
\mathrm{Si}=(\mathrm{wf}-\mathrm{wi}) / \mathrm{wf} \times 100
$$

where, wf is the final weight of the hydrated film, and wi is the initial weight of the dry film.

Film biodegradability was determined according to Martucci and Ruseckaite (2009) with modifications. The films were cut into circles with an area of $4 \mathrm{~cm}^{2}$, dehydrated in an oven at $65{ }^{\circ} \mathrm{C}$ to constant weight (wi) and packed in gauze with nine threads per $\mathrm{cm}^{2}$. Then, the film samples in gauze were placed at a depth of $2 \mathrm{~cm}$ in pots with Bioplant ${ }^{\circledR}$ substrate, which served as a degradation medium, and were kept in a greenhouse for 15 days under the same conditions as those used in the previous tests. At the end of this period, the film-containing gauzes were removed from the pots with tweezers and rinsed in running water. Then, the samples were dried at $65^{\circ} \mathrm{C}$ to constant weight. The percent biodegradability was determined using the following equation:

$$
\mathrm{WL}(\%)=(\mathrm{wf}-\mathrm{wi}) / \mathrm{wi} \times 100
$$

where, wi is the initial dry weight of the film, and wf is the dry weight remaining after 15 days of biodegradation.

Solubility was assessed based on Almeida et al. (2013) with modifications. For this purpose, the initial weight of a $2.7-\mathrm{cm}^{2}$ circular film sample was measured, then dried at $65{ }^{\circ} \mathrm{C}$ to constant weight. The weighed and dried samples (wi) were placed in Erlenmeyer containing $50 \mathrm{~mL}$ of water under magnetic stirring at $130 \mathrm{rpm}$ at room temperature for 24 hours. The resulting suspensions were filtered, and the residues were placed in an oven at $105^{\circ} \mathrm{C}$ for 24 hours to determine the final weight (wf). The solubility of the film was expressed as the percent solubilized weight over the dry weight.

\subsection{Statistical Analysis}

The experimental design was completely randomized. Six concentrations of sodium alginate were tested with six 10-plant replicates. Five concentrations of sodium alginate were tested with four replicates to characterize the capsules.

The data were subjected to the Shapiro-Wilk normality test. Qualitative data were subjected to analysis of variance, and the means were compared by the Tukey test at 5\% probability using Sisvar 5.6 software (Ferreira, 2011). Quantitative data were subjected to regression analysis using the SigmaPlot 11.0 software.

\section{Results}

\subsection{Effect of Encapsulation on Bud Chip Growth}

The sodium alginate concentration had a negative linear effect on the percent emergence and emergence speed index of sugarcane bud chips. These results suggest that sodium alginate capsules reduce the initial plant growth because they work as a barrier to emergence (Figure 3). 


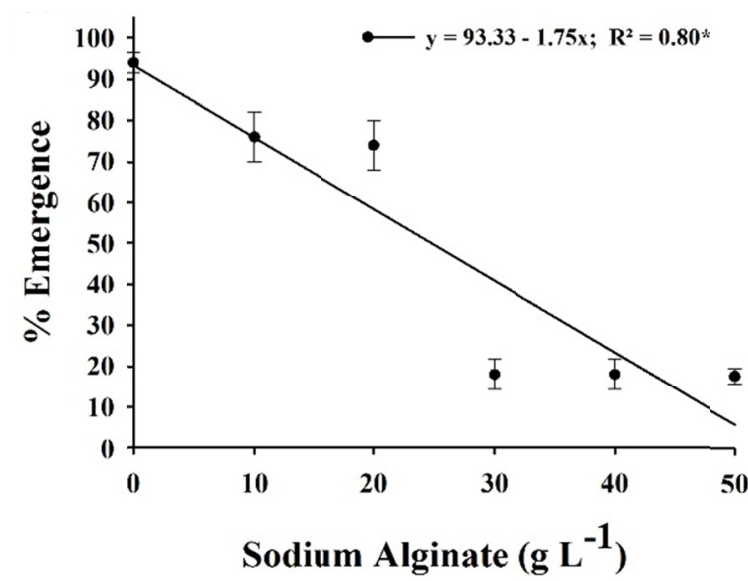

(a)

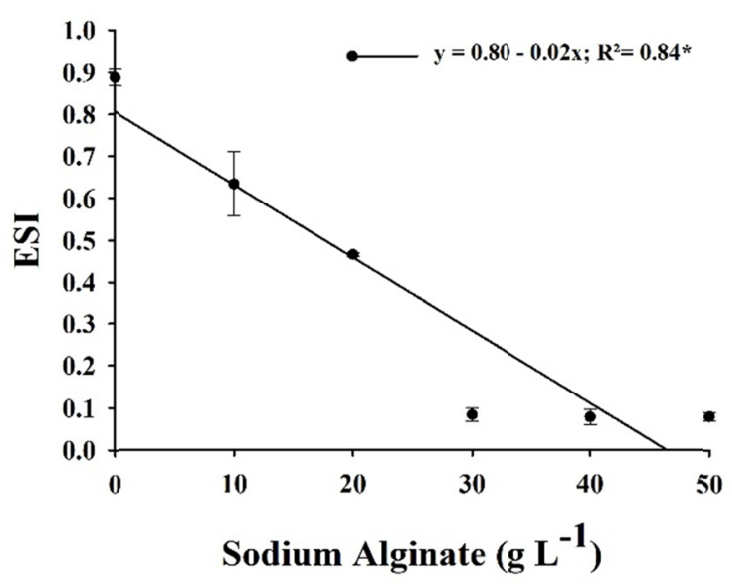

(b)

Figure 3. Percent emergence (a) and emergence speed index (ESI) (b) of bud chips of Saccharum sp. L., cultivar CTC 4, encapsulated with different concentrations of sodium alginate 31 days after planting

Emergence at concentrations zero and $10 \mathrm{~g} \mathrm{~L}^{-1}$ started at 8 days and stabilized 16 DAP. The bud chips encapsulated with $50 \mathrm{~g} \mathrm{~L}^{-1}$ sodium alginate started to emerge at 16 days, and emergence stabilized 31 DAP (Figure 4).

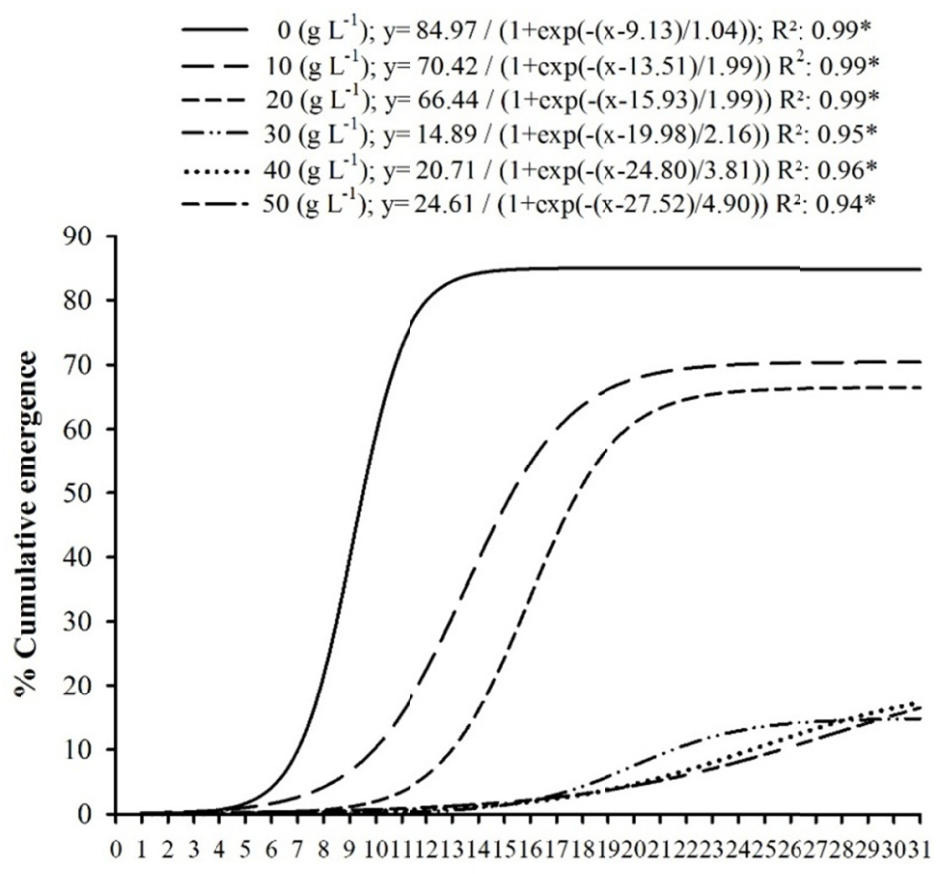

Days after planting

Figure 4. Cumulative percent emergence after planting bud chips of Saccharum sp. L., cultivar CTC 4, encapsulated with different concentrations of sodium alginate

Biometric analysis showed that the sodium alginate concentration has a negative linear effect on number of leaves, stem diameter, plant length, and shoot length (Figure 5). The effect on the longest root length was quadratic, indicating that roots that sprouted at a concentration of $50 \mathrm{~g} \mathrm{~L}^{-1}$ tended to grow more to optimize nutrient absorption. 


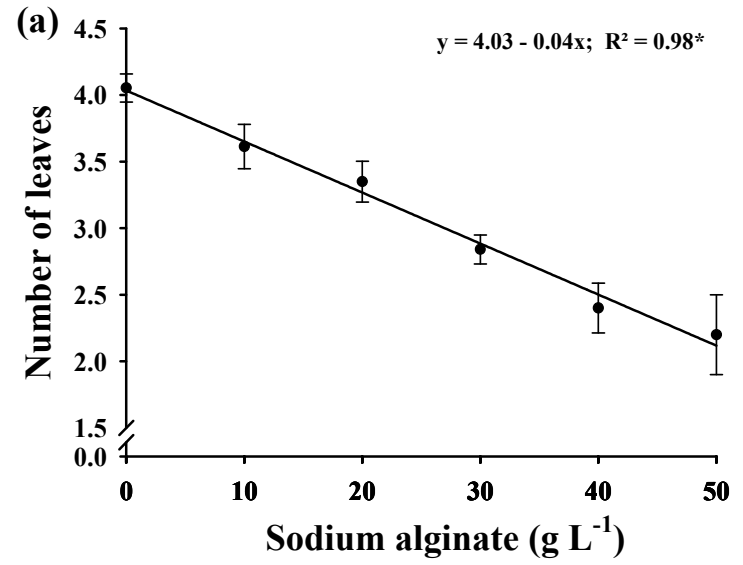

(c)

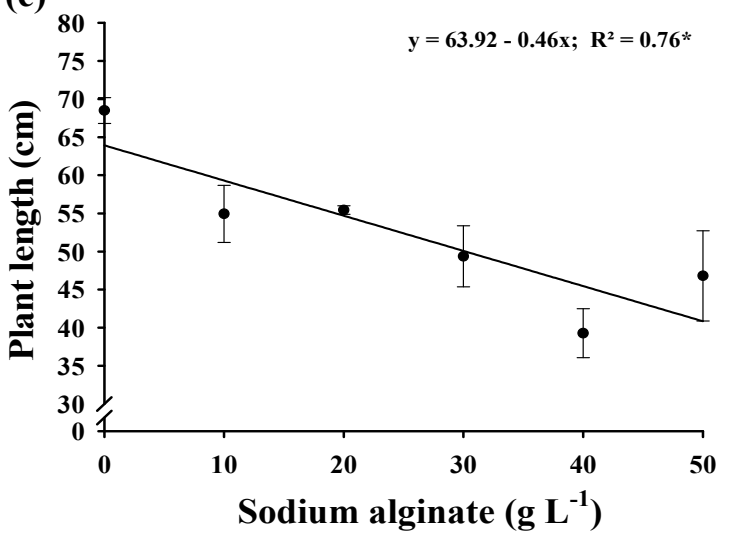

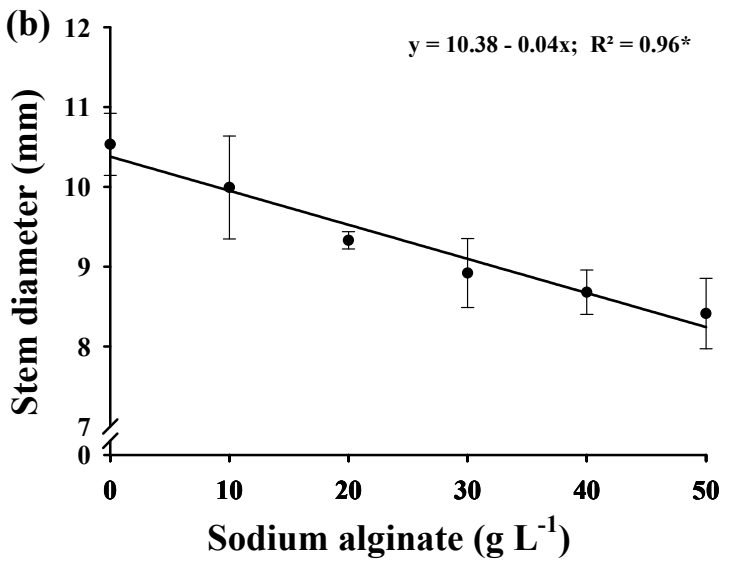

(d)

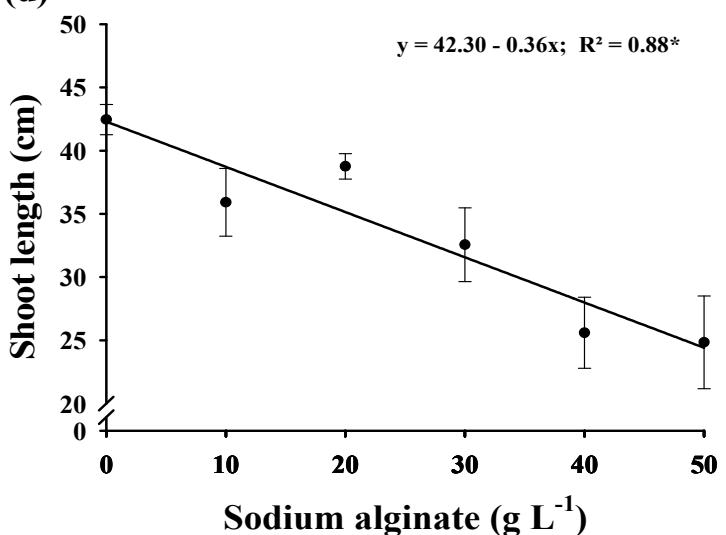

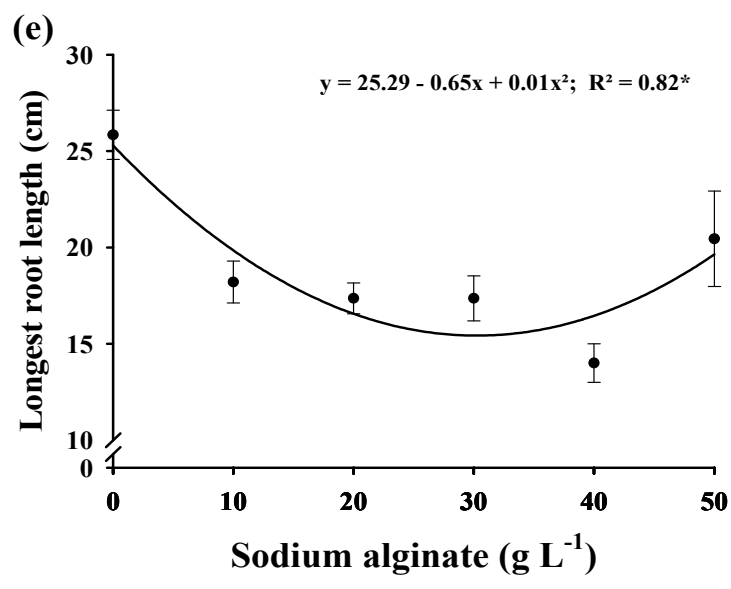

Figure 5. Regression analysis of number of leaves (a), stem diameter (b), plant length (c), shoot length (d), and longest root length (e) of seedlings of Saccharum sp. L., cultivar CTC 4, encapsulated with different concentrations of sodium alginate, 31 days after planting

The emerged sugarcane plants encapsulated with 30,40 , and $50 \mathrm{~g} \mathrm{~L}^{-1}$ sodium alginate lacked physiological quality for seedling production and did not differ significantly in SDM, RDM, or DMtotal — with 0.34, 0.10, and $0.44 \mathrm{~g}$, respectively - at 31 days after emergence. The concentrations of 0,10 , and $20 \mathrm{~g} \mathrm{~L}^{-1}$ did not differ significantly in SDM (1.17), RDM (0.62), or DMtotal (1.80) 59 days after planting; thus, growth was similar at these concentrations, regardless of the use of the sodium alginate.

Viability, assessed after removing the capsule and replanting the non-emerged bud chips from the 30, 40, and 50 $\mathrm{g} \mathrm{L}^{-1}$ concentrations, showed no significant difference in percent emergence or emergence speed index, with mean values of $59.71 \%$ and 0.55 , respectively. The emerged plants with capsule had $17.83 \%$ emergence and 0.08 
ESI (Figure 6). This demonstrates that the capsule preserves the ability of the plant to grow after the capsule is removed.
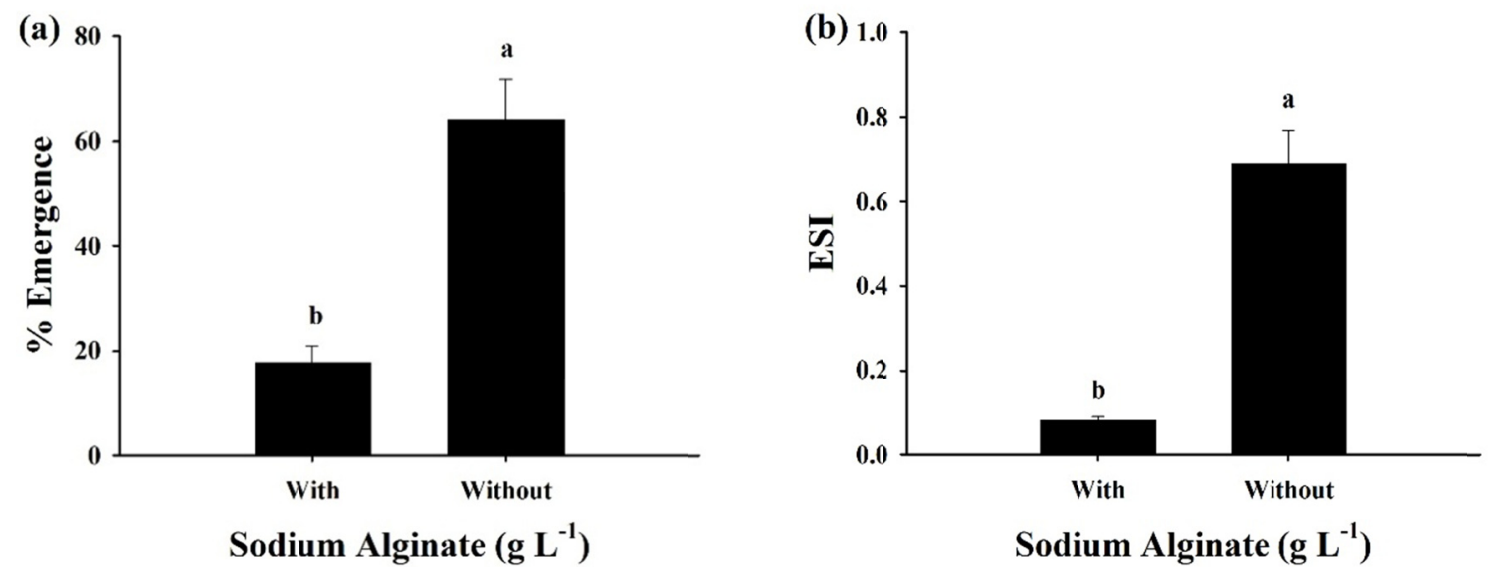

Figure 6. Percent emergence and emergence speed index (ESI) of bud chips of Saccharum sp. L., cultivar CTC 4, with capsule and after removing the capsule (without capsule). Different letters above the columns indicate significant differences according to the Tukey test at $5 \%$ probability

Analysis of the biometric variables showed no significant difference among the 30,40 , and $50 \mathrm{~g} \mathrm{~L}^{-1}$ concentrations with a mean of 1.94 leaves, $4.74 \mathrm{~mm}$ stem diameter, $12.65 \mathrm{~cm}$ longest root length, $27.15 \mathrm{~cm}$ shoot length, and $39.00 \mathrm{~cm}$ plant length. These concentrations also had no effect on the parameters shoot dry mass, root dry mass, or total dry mass with mean values of $0.72,0.54$, and 1.25 , respectively.

\subsection{Characterization of the Biofilm Used for Encapsulation}

In the assessment of the films, the variables BCAFDM and swelling index increased linearly with the sodium alginate concentration. The capsule formed with $10 \mathrm{~g} \mathrm{~L}^{-1}$ sodium alginate had the lowest $(0.034 \mathrm{~g})$ BCAFDM, and the highest BCAFDM $(0.656 \mathrm{~g})$ was observed at $50 \mathrm{~g} \mathrm{~L}^{-1}$. The increase in the BCAFDM shows the film's effect as a mechanical barrier to root growth (Figure 7). 

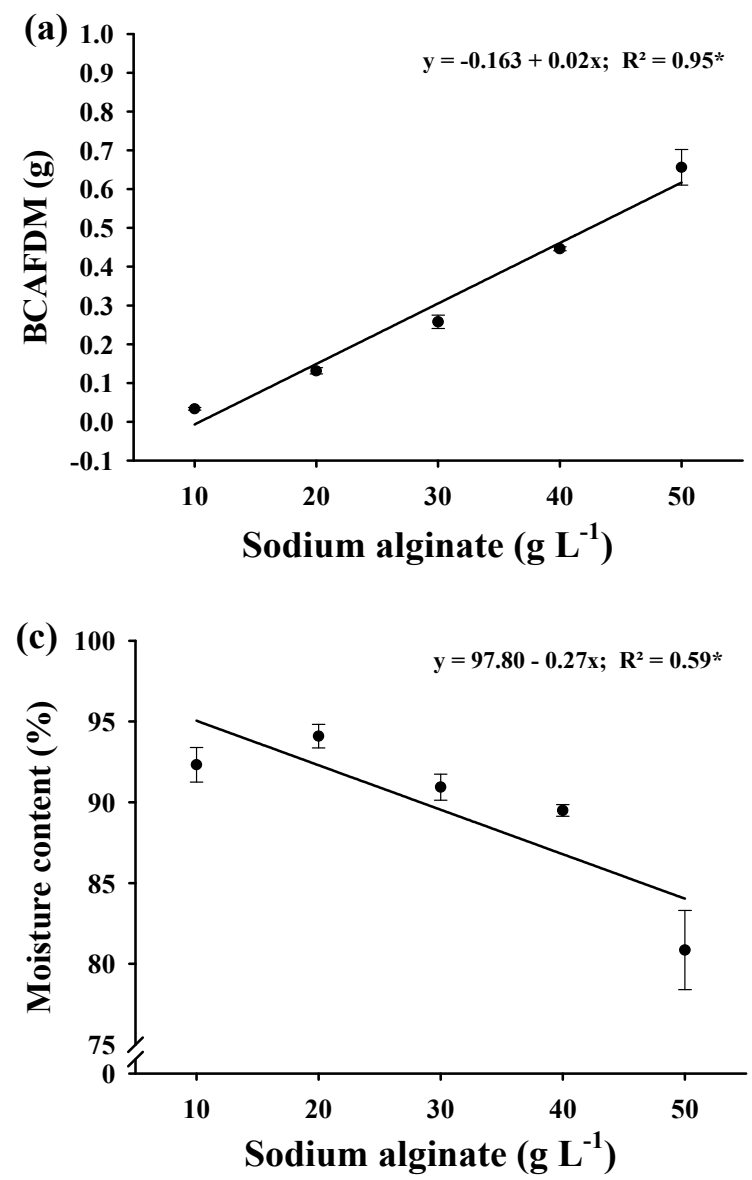
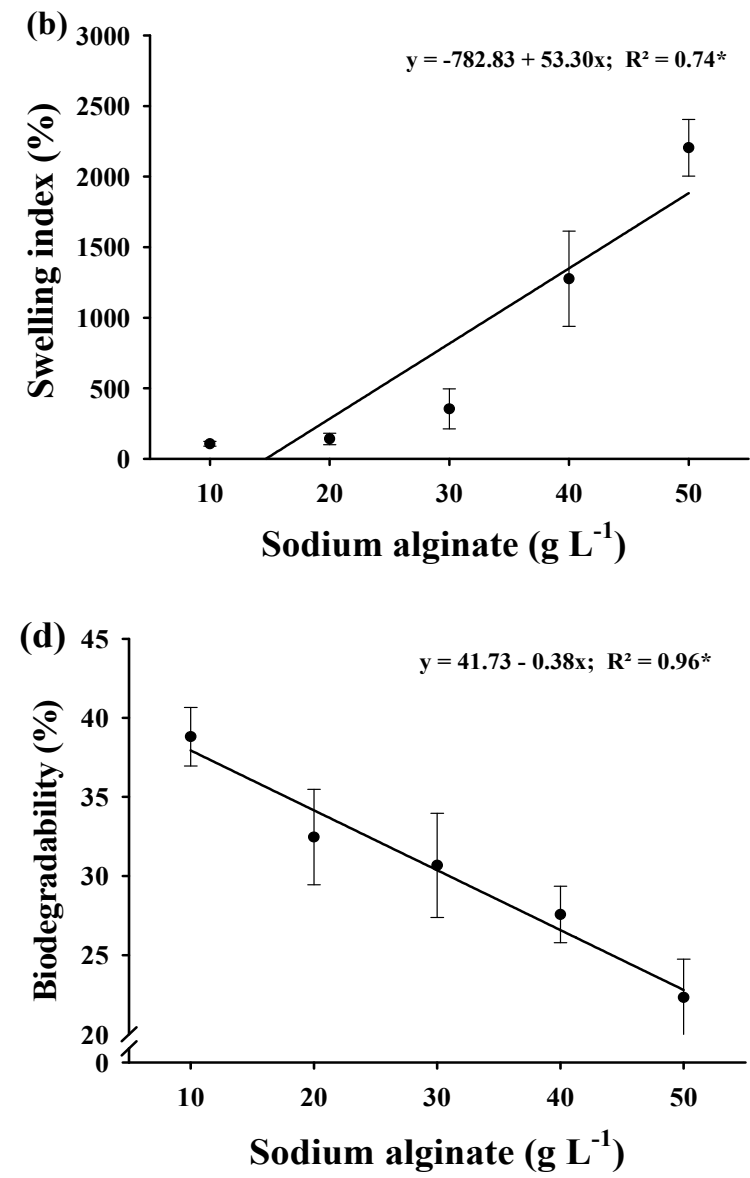

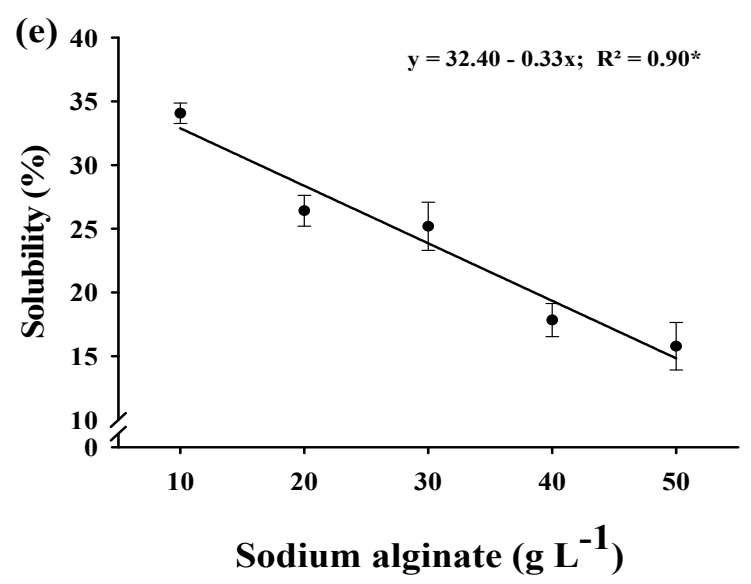

Figure 7. Analysis of the bud chip-adhered film dry mass (BCAFDM) (a), swelling index (b), moisture content (c), biodegradability (d), and solubility (e) of films with different concentrations of sodium alginate used for Saccharum sp. L. bud chip encapsulation

\section{Discussion}

Encapsulation is a micropropagation method widely used for synthetic seed formation, and it can also be used for plant propagule conservation (Rai, Asthana, Singh, Jaiswal, \& Jaiswal, 2009). However, the application of this method in the field is still underexplored. This is the first report of sugarcane bud chip encapsulation with sodium alginate in an ex vitro environment. Sodium alginate acted as a physical barrier and reduced sugarcane seedling emergence. 
The effect of sodium alginate concentration on the emergence of micropropagated synthetic seeds of Rauvolfia serpentina L. Benth. has also been reported and is associated with the synthetic seed firmness provided for by high sodium alginate concentrations (Gantait, Kundu, Yeasmin, \& Ali, 2017). The capsule formed by 30, 40, and $50 \mathrm{~g} \mathrm{~L}^{-1}$ sodium alginate cross-linked with calcium chloride may have had a tegument effect, preventing water absorption by the bud chip and causing mechanical resistance to root and shoot growth (Müller, Gibbert, Binotto, Kaiser, \& Bortolini, 2017).

The in vitro synthetic seed conversion into plants was affected by the composition of the sodium alginate solution and by the formulation of the sowing substrate, which may have additional nutrients, growth regulators, and protective agents (Faria, Costa, Londe, Silva, \& Ribeiro, 2014; Verma, Agarwal, Dubey, Solomon, \& Singh, 2013). Another key factor for synthetic seed conversion into plants is the use of different concentrations of sodium alginate.

Under in vitro conditions, the decline in the synthetic seed conversion into plants is attributed to extreme concentrations of sodium alginate and calcium chloride. The concentrations currently used for several species are $30 \mathrm{~g} \mathrm{~L}^{-1}$ sodium alginate and $75 \mathrm{mM}$ calcium chloride (Gantait et al., 2017). Because it is a physical barrier, the capsules prepared at the highest sodium alginate concentrations are an obstacle to root sprouting; although sodium alginate protects the propagule, the capsule also prevents its growth (Lambardi, Benelli, Ozudogru, \& Ozden-Tokatli, 2006).

Direct sowing of synthetic seeds and their formation under non-aseptic conditions is important for the propagation of widely cultivated commercial species. This method shortens the acclimatization required for in vitro cultures and allows the handling and transport of propagules. However, studies on nonsterile synthetic seed formation and their direct sowing must be adapted to each species. The success of large-scale synthetic seeds requires sowing under non-aseptic conditions, which shortens acclimatization, and removing organic compounds from both the encapsulation matrix and the substrate fertigation to avoid contamination, as performed in the present study (Hung \& Dung, 2015).

The use of synthetic seeds for commercial propagation of plant species is uncommon. Nyende, Schittenhelm, Mix-Wagner, and Greef (2005) report that in vitro precultivation of synthetic potato seeds is necessary for success in the field because direct sowing in the field had less than $18 \%$ emergence. No difference in sugar yield was found after 12 months of field cultivation when synthetic seed-acclimatized sugarcane plants were compared to macropropagated plants derived from pregerminated three-bud propagules and from single-node auxiliary buds (Nieves et al., 2003). These results demonstrate that precultivation is an alternative for the production of seedlings with good field performance and that nutrient solutions added to the growth medium stimulate the initial plant growth.

Considering that sugarcane propagules should be immediately planted after field cutting to avoid the deterioration of the material, encapsulation enabled a considerable emergence rate after capsule removal and replanting (Jain, Solomon, Shrivastava, \& Chandra, 2010). This demonstrates that encapsulation is also viable for short-term sugarcane storage because, even under greenhouse conditions, it preserved $59 \%$ of the bud chips for 59 days after sowing in substrate. Encapsulation with sodium alginate reduces microbial activity in propagules and the respiration and transpiration of the plant material; therefore, encapsulation may be used for conservation and may facilitate logistics processes for sugarcane germplasm exchange (Mannozzi et al., 2016).

The swelling index was lower at 10 and $20 \mathrm{~g} \mathrm{~L}^{-1}$ and higher at $50 \mathrm{~g} \mathrm{~L}^{-1}$ sodium alginate, and this is important to assess the water absorption capacity of the film (Figure 7). The higher swelling index in films with higher sodium alginate concentrations may result from lower cross-linking at higher concentrations, thus leading to a higher number of molecules available to interact with water (Almeida et al., 2013). The crosslinking process is very important for synthetic seed formation, and the optimal concentration should be determined for each study species (Javed, Alatar, Anis, \& Faisal, 2017).

The characteristic moisture content, biodegradability, and solubility decreased linearly with the sodium alginate concentration (Figure 7). Moisture content decreased with the increase in sodium alginate concentration; the mean moisture was $93.21 \%$ at 10 and $20 \mathrm{~g} \mathrm{~L}^{-1}$ sodium alginate, and the lowest moisture, $80.86 \%$, was observed at $50 \mathrm{~g} \mathrm{~L}^{-1}$ sodium alginate. This decrease in moisture likely occurred because the higher concentration of alginate molecules reduced the available water content (Jaramillo, Seligra, Goyanes, Bernal, \& Famá, 2015). Moisture is a key factor for plant growth because it enables cell expansion and consequently plant growth.

Biodegradability was highest at 10 and $20 \mathrm{~g} \mathrm{~L}^{-1}$ and lowest at $50 \mathrm{~g} \mathrm{~L}^{-1}$ sodium alginate. The biodegradation process is affected by the interaction between the sodium alginate biofilm and water and by the film size and 
shape (Laycock et al., 2017). Molecules interact strongly due to the higher concentration of sodium alginate, thereby reducing the biodegradability (Deepa et al., 2016; Emadian, Onay, \& Demirel, 2017).

The mean solubility of the sodium alginate concentrations was $22.61 \%$. This parameter is important because it affects the biodegradability of films and is directly related to their ability to interact with water. The low solubility of sodium alginate films is related to crosslinking with calcium chloride; thus, these films have lower solubility in water than hydroxypropylmethylcellulose films (Rotta et al., 2009). The optimal film for synthetic seed formation should have high solubility in water, which enables their biodegradability and, therefore, their plant growth.

This pioneering study showed that synthetic seed formation with concentrations of up to $50 \mathrm{~g} \mathrm{~L}^{-1}$ sodium alginate is not viable. However, the study of new encapsulation agents and methods for synthetic sugarcane seed formation will help develop innovative planting techniques, which may benefit the sugarcane industry, as there are many products for encapsulation and, therefore, for synthetic seed formation. In addition, the use of sodium alginate to encapsulate bud chips may be an alternative for short-term storage, enabling logistics processes and subsequent propagule planting.

\section{Conclusion}

Sodium alginate reduced sugarcane bud chip emergence and initial growth but can be used to preserve the physology quality. The nonviability of encapsulation for synthetic sugarcane seed formation may result from the characteristics of the sodium alginate capsules. New studies evaluating capsules with high swelling index, moisture content, biodegradability, and solubility should be performed. These capsules should also be studied to enable short-term sugarcane storage and logistics processes.

\section{References}

Almeida, D. M., Prestes, R. A., Pinheiro, L. A., Woiciechowski, A. L., \& Wosiacki, G. (2013). Propriedades físicas, químicas e de barreira em filme formados por blenda de celulose bacteriana e fécula de batata. Polímeros Ciência e Tecnologia, 23, 538-546. https://doi.org/10.4322/polimeros.2013.038

Borges, I. D., Franco, A. A. N., Kondo, M. K., Martins, D. C., Teixeira, E. C., \& Moreira, S. G. (2016). Acúmulo de macronutrientes na cultura do sorgo granífero na safrinha. Revista Brasileira de Milho e Sorgo, 15, 294-304. https://doi.org/10.18512/1980-6477/rbms.v15n2p294-304

Braga Jr, R. L. C., Landell, M. G. A., Silva, D. N., Bidóia, M. A. P., Silva, T. N., Thomazinho Jr, J. R., \& Silva, V. H. P. (2017). Censo varietal IAC de cana-de-açúcar na região Centro-Sul do Brasil-Safra 2016/17. Campinas: Instituto Agronômico (IAC).

Deepa, B., Abraham, E., Pothan, L., Cordeiro, N., Faria, M., \& Thomas, S. (2016). Biodegradable nanocomposite films based on sodium alginate and cellulose nanofibrils. Materials, 9(1), 50. https://doi.org/10.3390/ma9010050

Emadian, S. M., Onay, T. T., \& Demirel, B. (2017). Biodegradation of bioplastics in natural environments. Waste Management, 59, 526-536. https://doi.org/10.1016/j.wasman.2016.10.006

Faria, R. A. N., Costa, A. M., Londe, L. N., Silva, J. F., \& Ribeiro, E. B. (2014). Influência da composição da matriz de encapsulamento de microbrotos de banana (Musa sp.) cv. Prata-Anã clone Gorutuba. Revista Brasileira de Fruticultura, 36, 472-478. https://doi.org/10.1590/0100-2945-262/13

Ferreira, D. F. (2011). Sisvar: A computer statistical analysis system. Ciência e Agrotecnologia, 35, 1039-1042. https://doi.org/10.1590/s1413-70542011000600001

Gantait, S., Kundu, S., Yeasmin, L., \& Ali, M. N. (2017). Impact of differential levels of sodium alginate, calcium chloride and basal media on germination frequency of genetically true artificial seeds of Rauvolfia serpentina (L.) Benth. ex Kurz. Journal of Applied Research on Medicinal and Aromatic Plants, 4, 75-81. https://doi.org/10.1016/j.jarmap.2017.01.005

Gírio, L. A. S., Dias, F. L. F., Reis, V. M., Urquiaga, S., Schultz, N., Bolonhezi, D., \& Mutton, M. A. (2015). Bactérias promotoras de crescimento e adubação nitrogenada no crescimento inicial de cana-de-açúcar proveniente de mudas pré-brotadas. Pesquisa Agropecuária Brasileira, 50(1), 33-43. https://doi.org/ $10.1590 / \mathrm{s} 0100-204 \times 2015000100004$

Gomes, C. (2013). Sistema muda conceito de plantio. Jornal A Lavoura, Campinas, 696(1), 38-39. 
Hung, C. D., \& Dung, C. D. (2015). Production of Chrysanthemum synthetic seeds under non-aseptic conditions for direct transfer to commercial greenhouses. Plant Cell, Tissue and Organ Culture, 122, 639-648. https://doi.org/10.1007/s11240-015-0797-0

Hung, C. D., \& Trueman, S. J. (2011). Encapsulation technology for short-term preservation and germplasm distribution of the African mahogany Khaya senegalensis. Plant Cell, Tissue and Organ Culture (PCTOC), 107, 397-405. https://doi.org/10.1007/s11240-011-9990-y

Jain, R., Solomon, S., Shrivastava, A. K., \& Chandra, A. (2010). Sugarcane bud chips: A promising seed material. Sugar Tech, 12(1), 67-69. https://doi.org/10.1007/s12355-010-0013-9

Jaramillo, C. M., Seligra, P. G., Goyanes, S., Bernal, C., \& Famá, L. (2015). Biofilms based on cassava starch containing extract of yerba mate as antioxidant and plasticizer. Starch, 67, 780-789. https://doi.org/10.1002/ star.201500033

Javed, S. B., Alatar, A. A., Anis, M., \& Faisal, M. (2017). Synthetic seeds production and germination studies,for short term storage and long distance transport of Erythrina variegata L.: A multipurpose tree legume. Industrial Crops and Products, 105, 41-46. https://doi.org/10.1016/j.indcrop.2017.04.053

Kaya, E., \& Souza, F.V.D. (2017). Comparison of two PVS2-based procedures for cryopreservation of commercial sugarcane (Saccharum spp.) germplasm and confirmation of genetic stability after cryopreservation using ISSR markers. In Vitro Celular and Development Biology-Plant, 53, 410-417. https://doi.org/10.1007/s11627-017-9837-2

Lambardi, M., Benelli, C., Ozudogru, E. A., \& Ozden-Tokatli, Y. (2006). Synthetic seed technology in ornamental plants. In J. A. T. Silva (Ed.), Floriculture, ornamental and plant biotechnology: Advances and topical issues (pp. 347-354). UK: Global Science Books.

Landell, M. D. A., Campana, M., Figueiredo, P., Xavier, M., Anjos, I. D., Dinardomiranda, L. L., \& Mendonça, J. D. (2013). Sistema de multiplicação de cana-de-açúcar-de-açúcar com uso de mudas pré-brotadas $(M P B)$, oriundas de gemas individualizadas. Campinas: Instituto Agronômico.

Laycock, B., Nikolić, M., Colwell, J. M., Gauthier, E., Halley, P., Bottle, S., \& George, G. (2017). Lifetime prediction of biodegradable polymers. Progress in Polymer Science, 71, 144-189. https://doi.org/10.1016/ j.progpolymsci.2017.02.004

Maguire, J. D. (1962). Speed of germination-Aid in selection and evaluation for seedling emergence and vigor. Crop Science, 2(1), 176. https://doi.org/10.2135/cropsci1962.0011183x000200020033x

Mannozzi, C., Cecchini, J. P., Tylewicz, U., Siroli, L., Patrignani, F., Lanciotti, R., ... Romani, S. (2016). Study on the efficacy of edible coatings on quality of blueberry fruits during shelf-life. LWT-Food Science and Technology, 85, 440-444. https://doi.org/10.1016/j.lwt.2016.12.056

Martucci, J. F., \& Ruseckaite, R. A. (2009). Tensile properties, barrier properties, and biodegradation in soil of compression-Molded gelatin-dialdehyde starch films. Journal of Applied Polymer Science, 112, 2166-2178. https://doi.org/10.1002/app.29695

Müller, E. M., Gibbert, P., Binotto, T., Kaiser, D. K., \& Bortolini, M. F. (2017). Maturação e dormência em sementes de Peltophorum dubium (Spreng) Taub. de diferentes árvores matrizes. Iheringia. Série Botânica, $71,222-229$.

Nieves, N., Zambrano, Y., Tapia, R., Cid, M., Pina, D., \& Castillo, R. (2003). Field performance of artificial seed-derived sugarcane plants. Plant Cell, Tissue and Organ Culture, 75, 279-282. https://oi.org/10.1023/ a: 1025855611981

Nyende, A. B., Schittenhelm, S., Mix-Wagner, G., \& Greef, J. M. (2005). Yield and canopy development of field grown potato plants derived from synthetic seeds. European Journal of Agronomy, 22, 175-184. https://doi.org/10.1016/j.eja.2004.02.003

Passarin, D. M. M., Fernandes, R. Z., \& Perticarrari, G. (2014). Método para obtenção de propágulos vegetais para micropropagação de cana-de-açúcar, para produção de semente sintética de cana-de-açúcar, para armazenamento de semente sintética, para produção de mudas, propágulos viáveis, e, semente sintética de cana-de-açúcar. BR n ${ }^{\circ}$ WO2014153630. Retrieved June 20, 2017, from https://www.google.com/patents/ WO2014153630A1?cl=pt

Rai, M. K., Asthana, P., Singh, S. K., Jaiswal, V. S., \& Jaiswal, U. (2009). The encapsulation technology in fruit plants-A review. Biotechnology Advances, 27, 671-679. https://doi.org/10.1016/j.biotechadv.2009.04.025 
Rotta, J., Ozório, R. Á., Kehrwald, A. M., Barra, G. M. O., Amboni, R. D. M. C., \& Barreto, P. L. M. (2009). Parameters of color, transparency, water solubility, wettability and surface free energy of chitosan/hydroxypropylmethylcellulose (HPMC) films plasticized with sorbitol. Materials Science and Engineering: C, 29, 619-623. https://doi.org/10.1016/j.msec.2008.10.032

Sharma, S., Shahzad, A., \& da Silva, J. A. T. (2013). Synseed technology-A complete synthesis. Biotechnology Advances, 31, 186-207. https://doi.org/10.1016/j.biotechadv.2012.09.007

Verma, A. K., Agarwal, A. K., Dubey, R. S., Solomon, S., \& Singh, S. B. (2013). Sugar partitioning in sprouting lateral bud and shoot development of sugarcane. Plant Physiology and Biochemistry, 62, 111-115. https://doi.org/10.1016/j.plaphy.2012.10.021

\section{Copyrights}

Copyright for this article is retained by the author(s), with first publication rights granted to the journal.

This is an open-access article distributed under the terms and conditions of the Creative Commons Attribution license (http://creativecommons.org/licenses/by/4.0/). 